\title{
The Evaluation of Microcarcinoma in Differentiated Thyroid Cancers According to Old and New TNM Classification
}

\author{
Diferansiye Tiroid Kanserlerinde Eski ve Yeni TNM Sinılamasına Göre Mikrokarsinomun \\ Değerlendirilmesi
}

\author{
Zekiye Hasbekl, Bülent Turgutl, Taner Erselcan', Ayhan Koyuncu2', Mehmet Fatih Börksüz', Nergiz Hacer Turgut3, Fadime Yumukl \\ 'Cumhuriyet University, School of Medicine, Department of Nuclear Medicine, Sivas, Turkey \\ 2Cumhuriyet University, School of Medicine, Department of General Surgery, Sivas, Turkey \\ ${ }^{3}$ Cumhuriyet University, School of Veterinary, Department of Pharmacology and Toxicology, Sivas, Turkey
}

\begin{abstract}
Objective: In this study, we aimed to evaluate the tumor size for proximal and distant metastases when the new and old TNM classification is taken into account in differentiated thyroid cancers.

Material and Methods: Two hundred sixty eight patients diagnosed with thyroid carcinoma, undergoing bilateral total or subtotal thyroidectomy treated with high doses of I-131 were examined retrospectively. The data of these patients were compared after classification, according to tumor size $\leq 1 \mathrm{~cm}$ and $\leq 2 \mathrm{~cm}$, lymph node metastases thyroid and tumor capsule invasion at the time of diagnosis, and accumulation of abnormal activity in post I-131 treatment whole-body scan. I-131 uptakes besides physiological and thyroid bed were considered as abnormal activity uptakes.

Results: A total of 268 patients with average age of 19-82 yrs (mean: 47.0 $113.8 \mathrm{yrs}$ ) were included in the study. At postoperative histopathological evaluation, 228 (85.1\%) of patients were reported as papillary, $13(4.9 \%)$ as follicular, $23(8.6 \%)$ as well differentiated tumor of unknown malignant potential, $2(0.7 \%)$ as insular and $2(0.7 \%)$ as Hürthle-cell carcinoma. In patients with known tumor size, 96 of 207 (46.4\%) patients' tumor size was $\leq 1 \mathrm{~cm}$ and in $111(53.6 \%)>1 \mathrm{~cm}$. In the same group, according to the revised TNM classification, in 149 of 207 patients (72\%) the tumor size was $\leq 2 \mathrm{~cm}$, whereas in $58(28 \%)>2 \mathrm{~cm}$. Of 187 patients with negative lymph nodes, 15 (8\%) showed abnormal activity accumulation in the first post l-131 treatment whole-body scan and 10 (40\% of 25 patients) positive lymph node $(p<0.05)$ involvement.

Conclusion: Since the treatment of patients with microcarcinoma is controversial, tumor size should not be the only factor considered in patients with differentiated thyroid cancer. Tissue tumor invasion, age, gender and multifocality should also be taken into account. (MIRT 2011;20:94-99)
\end{abstract}

Key words: $1-131$, microcarcinoma, differentiated thyroid carcinoma, TNM classification

\section{Özet}

Amaç: Bu çalışma ile diferansiye tiroid kanserlerinde eski ve yeni TNM sınıflaması dikkate alındığında, tümör boyutunun yakın ve uzak metastaz açısından değerlendirilmesi amaçlanmıştır.

Gereç ve Yöntemler: Bu çalışmada tiroid karsinomu tanısı almış, bilateral total veya subtotal tiroidektomi yapılmış ve yüksek doz I-131 ile tedavi almış olan 268 hastanın verileri retrospektif olarak incelenmiştir. Tanı anında lenf nodu metastazı, tiroid ve tümör kapsül invazyonu olan ve cerrahi tedavisinin ardından yüksek doz I-131 tedavisi verildikten sonra tedavi sonrası I-131 tüm vücut tarama sintigrafisinde anormal aktivite akümülasyonu gösteren hastalarda tümör boyutunun $\leq 1 \mathrm{~cm}$ ve $\leq 2 \mathrm{~cm}$ olmasına göre sınıflama yapıldığında elde edilen veriler karşılaştırılmıştır. I-131'in fizyolojik ve tiroid yatağı dışındaki tutulumları anormal aktivite tutulumu olarak kabul edilmiştir.

Address for Correspondence: Zekiye Hasbek MD, Cumhuriyet University, School of Medicine, Department of Nuclear Medicine, Sivas, Turkey Phone: +90 3462580253 E-mail: zmhasbek@yahoo.com Received: 13.06.2011 Accepted: 24.10.2011

23. National Congress of Nuclear Medicine, April 27-May 01 2011, Swissotel, Izmir, Türkiye Molecular Imaging and Radionuclide Therapy, published by Galenos Publishing. 


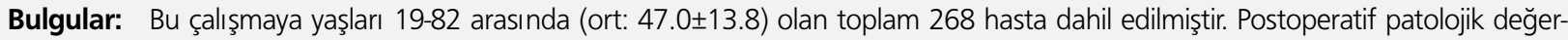
lendirmede hastalarımızdan 228'i (\%85.1) papiller, 13'ü (\%4.9) foliküler, 23'ü (\%8.6) malign potansiyeli bilinmeyen iyi diferansiye, 2'si (\%0.7) insüler ve 2'si (\%0.7) Hürthle hücreli karsinom olarak rapor edilmiştir. Tümör boyutu bilinen 207 hastanın 96'sında (\%46.4) tümör boyutu $\leq 1 \mathrm{~cm}, 111^{\prime}$ inde (\%53.6) $>1 \mathrm{~cm}$ idi. Aynı grupta revize TNM sınıflamasına göre tümör boyutu $\leq 2 \mathrm{~cm}$ hastalar dikkate alındığında; 207 hastanın 149'unda (\%72) tümör boyutu $\leq 2 \mathrm{~cm}, 58$ 'inde (\%28) ise >2 cm idi. Lenf nodu tutulumu negatif olan 187 hastanın ilk I-131 tedavi sonrası tarama sintigrafisinde patolojik aktivite akümülasyonu olan 15 hasta (\% 8) varken, lenf nodu tutulumu pozitif olan 25 hastanın ise 10'unda (\% 40) tarama sintigrafisinde patolojik tutulum vardı $(p<0.05)$.

Sonuç: Mikrokarsinomalı hastaların tedavisi halen tartışmalı olduğundan, tümör boyutu diferansiye tiroid kanserli hastalarda dikkate alınacak tek faktör olmamalıdır. Tümör invazyonu, yaş, cinsiyet ve multifokalitenin de dikkate alınması gerekir. (MIRT 2011,20:94-99)

Anahtar kelimeler: I-131, mikrokarsinom, diferansiye tiroid karsinom, TNM sınıflama

\section{Introduction}

Papillary thyroid carcinoma (PTC), follicular (FTC) and Hürthle cell carcinoma are derived from thyroid follicle cells and termed as differentiated thyroid carcinomas (DTC). PTC incidence is higher than follicular and other types of thyroid cancer and continues to increase with time. The increase of PTC incidence is the main cause of the incidence increase, as $85 \%$ of all thyroid cancers (1). It is thought that one of the reasons for this is the increased use of high-tech ultrasound equipment, and the widespread use of fine needle aspiration biopsy (2). Because of the high prevalence compared to other thyroid cancers, PTC is the most frequent histological group for mortality. (3). While incidences of FTC and medullary thyroid cancer are relatively stable, there is a reduction in the incidence of anaplastic cancers. Although PTC and FTC derive from thyroid follicular cells, and have different clinical behavior; the former prefers to invade via lymphatics to regional lymph nodes and lung, while the latter to bone by hematogenous way (4). Although lymphatic invasion is frequent in papillary thyroid carcinoma, hematogenous invasion, especially in small lesions is not seen very often. Adjacent lymph node metastases at diagnosis are seen in about the half of the cases (5) while the possibility of seeing distant metastases is much lower. However, the risk of tumor-related mortality is higher for distant metastases compared to local recurrences, due to newly appeared metastases in distant organs from aggressive primary lesions which tend to grow more rapidly (6). Tumor size is an important prognostic factor in PTCs. Cancer-specific mortality rate increases with increasing tumor size (1). The treatment of choice for thyroid cancer is surgery. DTCs capture, organify iodine and have the ability to synthesize and release thyroglobulin $(\mathrm{Tg})$. Because of this feature, DTCs can be treated with high doses of radioactive iodine (I-131) after thyroidectomy. Remnants of thyroid tissue after thyroidectomy are also treated by I-131. Elevated levels of serum $\operatorname{Tg}(>2 \mathrm{ng} / \mathrm{ml})$, is a specific indicator with high sensitivity and means presence of residual thyroid tissue, metastatic focus or recurrence $(4,7,8)$. In addition, post-ablation whole-body scintigraphy provides the detection of unknown metastatic foci and treatment of microscopic tumor foci (9). Thus, thyroid carcinomas, even at very small sizes can be determined.

In clinical practice, tumor size $\leq 1 \mathrm{~cm}$ is defined as "microcarcinoma". According to the old tumor, node, and metastasis (TNM) classification, group of patients with tumor size $\leq 1 \mathrm{~cm}$ was considered to be $T 1$, whereas in the new TNM classification tumor size $\leq 2 \mathrm{~cm}$ is considered to be T1 (10). Currently, frequently discussed topic is the treatment plan of microcarcinomas. According to the American Thyroid Association (ATA) Manual (10) in patients with a tumor diameter $<1 \mathrm{~cm}$, low-risk group, one-sided tumor, no history of head and neck radiation, no family history, no clinical and radiological cervical lymph node metastases and patients with the tumor localized in the thyroid, it is suggested that only lobectomy may be sufficient $(11,12)$. However, other authors suggest that in all patient groups total or near total thyroidectomy is recommended. In addition, some guidelines also recommend total thyroidectomy with neck dissection (13). DTCs are usually curable, with good prognosis, although showing slow progress they can develop recurrence and metastases over time. Apart from tumor size and spread, the patient's age, gender, tumor's histological grade, presence of regional and distant metastases at diagnosis are extremely important factors and have to be taken under serious consideration.

The purpose of this study is to evaluate the relationship between tumor size and lymph node metastasis, capsular invasion and the pathological accumulation in the 1-131 whole body scintigraphy by classifying according to the old and new TNM classification.

\section{Materials and Methods}

Patients who presented between the years 2007-2010 at Cumhuriyet University Medical School Hospital, diagnosed with thyroid carcinoma, undergoing bilateral total or subtotal thyroidectomy and treated with high doses of 
radioactive I-131 were examined retrospectively. In this patient group, with lymph node metastasis, thyroid and tumor capsule invasion at the time of diagnosis and in patients who showed accumulation of abnormal activity in whole body scan were compared after classification according to tumor size $\leq 1 \mathrm{~cm}$ and $\leq 2 \mathrm{~cm}$. The I-131 uptakes besides physiological and thyroid bed were considered as abnormal activity uptakes.

SPSS 15.0 software was used for statistical analysis. The chi-square test was applied to evaluate the statistical significance of the parameters, Significance levels were presented as $p$ values. It was assumed that the observed differences were statically significant at the $p \leq 0.05$ levels.

\section{Results}

A total of 268 patients with an age range of 19-82 yrs (mean: 47.0 $\pm 13.8 \mathrm{yrs}$ ) were included in this study. Demographic and clinicopathologic characteristics are listed in Table 1. Patients were given doses of I-131 ranging from 90-314 mCi (mean: $116.4 \pm 25.8 \mathrm{mCi}$ ) orally. 223 patients $(83.2 \%)$ were female and $45(16.8 \%)$ were male. Hundred twenty one patients (45.1\%) were under the age 45 and 147 patients (54.9\%) over 45 . At postoperative pathological evaluation 228 (85.1\%) of patients were reported as papillary, $13(4.9 \%)$ as follicular, $23(8.6 \%)$ as well differentiated tumor of unknown malignant potential, $2(0.7 \%)$ as insular and 2 (0.7\%) as Hürthle cell carcinoma. In 96 of 207 (46.4\%) patients tumor size was $\leq 1 \mathrm{~cm}$ and in 111 $(53.6 \%)>1 \mathrm{~cm}$. In the same group, in 149 of 207 patients $(72 \%)$ the tumor size was $\leq 2 \mathrm{~cm}$ and in $58(28 \%)>2 \mathrm{~cm}$ according to the revised TNM classification.

In our study, using both old and new TNM classifications the relationship between tumor size and lymph node metastasis, capsular invasion, and the total body scintigraphy findings after high doses of I-131 was evaluated.

According to lymph node metastases, from 221 patients in whom lymph node involvement was stated, in pathological assessment, 194 (87.8\%) lymph node metastases were negative, while $27(12.2 \%)$ positive. In 5 $(23.8 \%)$ of 21 patients with known tumor size and lymph node metastases, tumor size was $\leq 1 \mathrm{~cm}$ and according to the revised TNM there were 8 (38.1\%) with tumor size $\leq 2$ $\mathrm{cm}$ (Table 2). Of 187 patients with negative lymph nodes in pathological evaluation, 15 (8\%) patients showed abnormal activity accumulation on first high-dose radioactive iodine scan, while abnormal accumulation was seen in 10 (40\%) of 25 patients with positive lymph nodes $(p<0.05)$. In 34 patients with known tumor size and thyroid capsular invasion, tumor size was $\leq 1 \mathrm{~cm}$ in $8(23.5 \%)$ patients and according to revised TNM classification it was 14 (41.2\%) (Table 2). When tumor capsule invasion was noticed, according to the revised TNM classification, of 56 patients with known tumor size and tumor capsular invasion, tumor size was $\leq 2 \mathrm{~cm}$ in 31 (55.4\%) patients and according to the old classification, tumor size was $\leq 1 \mathrm{~cm}$ in 17 $(30.4 \%)$ patients. In posttherapy whole body scans in patients who received high doses of 1-31 after surgical excision, $5(21.7 \%)$ were positive with tumor size $\leq 1 \mathrm{~cm}$ and $10(43.5 \%)$ with tumor size $\leq 2 \mathrm{~cm}$ (Table 2$)$.

\section{Discussion}

Thyroid carcinomas are the most common cancers of the endocrine system and papillary carcinoma is the most widespread type. In a study done by Davies et al (14) which evaluates the patient groups between the years 1973-2002 an increased incidence of papillary cancer was seen and no significant change in the incidence of follicular, medullary and anaplastic cancers was observed. It is thought that the increase in the incidence of papillary cancer depends on the developments in ultrasonography and fine-needle aspiration biopsy and this also leads to increase in the detection of small size cancers. In the same study, for the group with

Table 1. Demographic and clinicopathologic characteristics

\begin{tabular}{|c|c|}
\hline Characteristics & n (\%) \\
\hline \multicolumn{2}{|l|}{ Age } \\
\hline Mean age at diagnosis (years) (range) & 47.0 (19-82 yrs) \\
\hline$<45$ years & $121(45.1 \%)$ \\
\hline$\geq 45$ years & $147(54.9 \%)$ \\
\hline \multicolumn{2}{|l|}{ Sex } \\
\hline Female & $223(83.2 \%)$ \\
\hline Male & $45(16.8 \%)$ \\
\hline Tumor size (mm) (range) & $18.12 \mathrm{~mm}(1-90 \mathrm{~mm})$ \\
\hline \multicolumn{2}{|l|}{ LN metastasis } \\
\hline Present & $27(12.2 \%)$ \\
\hline Absent & $194(87.8 \%)$ \\
\hline \multicolumn{2}{|l|}{ WBS abnormal uptake } \\
\hline Positive & $30(11.7 \%)$ \\
\hline Negative & $226(88.3 \%)$ \\
\hline \multicolumn{2}{|l|}{ Histopathological Classification } \\
\hline Papillary & $228(83.2 \%)$ \\
\hline Follicular & $13(4.9 \%)$ \\
\hline $\begin{array}{l}\text { Well differentiated tumor of } \\
\text { unknown malignant potential }\end{array}$ & $23(8.6 \%)$ \\
\hline Insular & $2(0.7 \%)$ \\
\hline Hürthle cell & $2(0.7 \%)$ \\
\hline
\end{tabular}


tumor size $\leq 1 \mathrm{~cm}$, a $49 \%$ incidence increase was found while for those $\leq 2 \mathrm{~cm}$ an $87 \%$ increase was observed. It was shown that despite the increase in incidence, mortality remained stable (14). In our study, 228 (85.1\%) of 268 patients had papillary cancer.

The prognosis of thyroid cancer is excellent when appropriate treatment is applied. Ten year survival is reported in an approximately $85 \%$ of the cohort and in those with distant metastasis a $25-40 \%$ was referred (15). The presence of many factors such as age, sex, tumor histological grade, tumor size, multifocality, regional and distant metastases at diagnosis is effective on prognosis of differentiated thyroid carcinomas. The large size of the tumor, the presence of lymph node metastases, spread beyond the thyroid capsule, advanced age and male gender have been considered as bad prognostic factors (16). Papillary carcinomas prefer to invade regional lymph nodes and lung, while follicular carcinomas, go to the bone by hematogenous way (4). Approximately half of the patients with PTC have lymph node metastases at diagnosis (5). The effects of the presence of lymph node metastases on thyroid cancer prognosis are known. Especially the presence of bilateral or cervical lymph node metastases or invasion at lymph node capsule are bad prognostic features increasing the risk of regional and distant metastases $(7,17)$. Machens et al. (18) found the probability of lymphogenic micrometastasis significantly increased in papillary thyroid cancer above a tumor diameter cut-off of $5 \mathrm{~mm}$. Therefore, the small PTC is not always synonymous with a low-risk constellation, especially considering that lymph node spread is a risk factor for distant metastasis in PTC. In clinically lymph nodenegative patients, usually during surgery or during the

Table 2. The relationship between the tumor size and lymph node metastasis, thyroid capsular invasion, and the post-131/ treatment whole-body scan findings

\begin{tabular}{|c|c|c|c|c|}
\hline & & \multicolumn{3}{|c|}{ Tumor Size } \\
\hline & & $\leq 2 \mathrm{~cm}$ & $>2 \mathrm{~cm}$ & Total \\
\hline \multirow[t]{3}{*}{ Lymph Node Involvement } & Negative & $131(74.4 \%)$ & $45(25.6 \%)$ & 176 \\
\hline & Positive & $8 \quad(38.1 \%)$ & $13(61.9 \%)$ & 21 \\
\hline & Total & 139 & 58 & 197 \\
\hline \multirow[t]{3}{*}{ Thyroid Capsule Invasion } & Negative & 117 (76.5\%) & $36(23.5 \%)$ & 153 \\
\hline & Positive & $14 \quad(42.4 \%)$ & $20(57.6 \%)$ & 34 \\
\hline & Total & 131 & 56 & 187 \\
\hline Pathological Accumulation & Negative & $131(74.4 \%)$ & $45(25.6 \%)$ & 176 \\
\hline \multirow[t]{4}{*}{ (outside the thyroid bed } & Positive & $10 \quad(43.5 \%)$ & $13(56.5 \%)$ & 23 \\
\hline & Total & 141 & 58 & 199 \\
\hline & & \multicolumn{3}{|c|}{ Tumor Size } \\
\hline & & $1 \mathrm{~cm}$ & $>1 \mathrm{~cm}$ & Total \\
\hline \multirow[t]{3}{*}{ Lymph Node Involvement } & Negative & $82(46.6 \%)$ & $94(53.4 \%)$ & 176 \\
\hline & Positive & $5(23.8 \%)$ & $16(76.2 \%)$ & 21 \\
\hline & Total & 87 & 110 & 197 \\
\hline \multirow[t]{3}{*}{ Thyroid Capsule Invasion } & Negative & 75 (49\%) & 78 (51\%) & 153 \\
\hline & Positive & $8(23.5 \%)$ & $26(76.5 \%)$ & 34 \\
\hline & Total & 83 & 104 & 187 \\
\hline Pathological Accumulation & Negative & $85(48.3 \%)$ & $91(51.7 \%)$ & 176 \\
\hline \multirow[t]{2}{*}{ (outside the thyroid bed) } & Positive & $5 \quad(21.7 \%)$ & $18(78.3 \%)$ & 23 \\
\hline & Total & 90 & 109 & 199 \\
\hline
\end{tabular}


pathological examination of the material removed, lymph node metastases can be detected. In most patients lymph node metastases develop at the central compartment (10). In one study, in patients with clinically lymph node-negative papillary thyroid microcarcinoma, subclinical central lymph node metastases have been reported in a $36.7 \%$. However, it has been also stated that the removal of undetected central lymph nodes prior to the surgery as prophylactic technique has low benefit in the prognosis (19). In our patient group, abnormal accumulation of activity was seen on the first high-dose I-131 scintigraphy in 15 of 187 (8\%) patients with negative lymph nodes; on screening scan abnormal activity was noticed in 10 of $25(40 \%)$ patients with positive lymph node involvement.

The actual cause of death in PTC is the distant metastases. According to a study done by Ozkan et al (20), worse prognosis is found in patients who developed distant metastasis during follow-up compared to those with distant metastases at first diagnosis. Differentiated thyroid carcinomas have the ability to capture and organify iodine and also synthesize and release thyroglobulin. Because of this feature, DTCs can be treated with high doses of 1311 after thyroidectomy. Complete removal of the thyroid is rare and in most cases with post-operative I-131 scintigraphy, functioning thyroid tissue is detected (21). Thyroidectomy is thus completed with total ablation. Whole body scintigraphy taken after treatment with $\mathrm{I}-131$ is very valuable in predicting prognosis and deciding if additional treatment may be needed. The sensitivity for residual tumor and recurrence is $50-90 \%$, specificity is $80-100 \%$ (22). While there is 10 -year survival in $92 \%$ of patients with negative $1-131$ scintigraphy at treatment dose, this rate falls to $19 \%$ in those with positive scan (1). In our study, in $40 \%$ of patients with positive lymph nodes, pathological activity accumulation was observed in the post 1-131 treatment whole-body scan. In addition, we observed pathological uptake outside the thyroid bed in 5 of 90 (5.6\%) patients with tumor size $\leq 1 \mathrm{~cm}$ in the whole body scan after I-131 treatment. In the whole body scan of the same group of patients with regard to the new TNM classification, pathological uptake was seen in 10 of 141 (7.1\%) patients.

Mazzaferri et al. (17) have reported that recurrence significantly decreases in patients with papillary cancer who had total or subtotal thyroidectomy, ablation with I-131 and L-thyroxine therapy compared to patients who had only total thyroidectomy and treated with L-thyroxine. Recurrence or residue in DTCs is important indicators of morbidity and these are troubled conditions requiring new therapeutic applications (3). In a study in the follow-up of patients who received total thyroidectomy and successful ablation, no significant difference was found between high risk group and low risk group in terms of recurrence (23).
In a study done by Ito et al (24), in 2638 patients with tumor diameter $\leq 2 \mathrm{~cm}$ and being T1NOMO without radioactive iodine treatment a $0.2 \%$ developed distant metastases, and one patient died of thyroid cancer. In another study, in which Fukushima et al (25) evaluated 5917 patients, 2 patients developed distant metastases with tumor size $\leq 1 \quad(n=1,261)$, whereas in 40 local recurrence was detected. In patients with tumor size 1.1-2 $\mathrm{cm}, 16$ distant metastases were depicted and 85 local recurrences were detected. Of these patients, 2 with tumor size $\leq 1 \mathrm{~cm}$ and 8 with tumor size $1.1-2 \mathrm{~cm}$ died. Only one of our patients died 5.4 years after diagnosis due to brain metastasis of thyroid carcinoma. And this patient's tumor size at diagnosis was reported as $7 \mathrm{~mm}$.

The differentiated thyroid cancer follow-up protocol should be determined on the basis of the first treatment results instead of the classification of the tumor at first diagnosis. To make a risk classification according to ATA's guide, the risk should be determined for patients after receiving treatment with I-131 following total thyroidectomy and the follow-up protocol should be produced according to this evaluation.

\section{Conclusion}

We think that at the approach to thyroid cancer, particularly papillary thyroid cancer, instead of determining the treatment plan considering the tumor size either $\leq 1$ $\mathrm{cm}$, or $\leq 2 \mathrm{~cm}$ in the first place; the invasion of the tumor (lymph node, thyroid capsule, the surrounding tissue, etc.), patient age, gender, and multifocality in the surgical and clinical approach would be more accurate. Determining the treatment plan tumor size should not be the only factor of choice in papillary thyroid cancer. A plethora of other factors has to be taken into account like tissue tumor invasion, age, gender and multifocality.

\section{References}

1. Sipos JA, Mazzaferri EL. Thyroid Cancer Epidemiology and Prognostic Variables. Clin Oncol (R Coll Radiol) 2010;22:395-404.

2. Besic N, Pilko G, Petrik R, Hocevar M, Zgajnar J. Papillary Thyroid Microcarcinoma: Prognostic Factors and Treatment. J Surg Oncol 2008;97:221-225.

3. Amdur JA, Mazzaferri EL. Incidence, Prevalence, Recurrence, and Mortality of Differentiated Thyroid Cancer. In: Amdur JA, Mazzaferri EL (eds). Essentials of Thyroid Cancer Management. Springer Science+Business Media, Inc. 2005 p:121-41.

4. Martin WH, Sandler MP. Thyroid Imaging. Chapter 30-31. In: Sandler MP, Coleman RE; Patton JA, Wackers FJ, Gottschalk A (eds). Diagnostic Nuclear Medicine. 4th ed. Lippincott Williams\&Wilkins; Philadelphia 2003; p:607-670.

5. Robbins LS, Cotran SR, Kumar V. Basic Pathology (Temel Patoloji). Bölüm 20 Endokrin Sistem Hastalıkları; (Çeviri editörü Çevikbaş U) 6. Baskı. Nobel Tıp Kitabevleri Ltd. Şti, İstanbul 2000; s:649-53. 
6. Ito Y, Higashiyama T, Takamura Y, Kobayashi K, Miya A, Miyauchi A. Clinical Outcomes of Patients with Papillary Thyroid Carcinoma after the Detection of Distant Recurrence. World J Surg 2010;34:2333-2337.

7. Verburg FA, Dietlein $M$, Lassmann $M$, Luster $M$, Reiners $C$. Why radioiodine remnant ablation is right for most patients with differentiated thyroid carcinoma. Eur J Nuc Med Mol Imaging 2009;36:343-346.

8. Lubin E, Mechlis-Frish S, Zatz S, Shimoni A, Segal K, Avraham A, Levy R, Feinmesser. Serum Thyroglobulin and lodine-131 WholeBody Scan in the Diagnosis and Assessment of Treatment for Metastatic Differentiated Thyroid Carcinoma. J Nucl Med 1994;35:257-262.

9. Pacini F, Schlumberger M, Dralle H, Elisei R,.Smit JW, Wiersinga W; Europan Thyroid Cancer Taskforce. Europan consensus for the management of patients with differrentiated thyroid carcinoma of the follicular epithelium. Eur J Endocrinol 2006;154:787-803.

10. American Thyroid Association (ATA) Guidelines Taskforce on Thyroid Nodules and Differentiated Thyroid Cancer, Cooper DS, Doherty GM, Haugen BR, Kloos RT, Lee SL, Mandel SJ, Mazzaferri EL, Mclver B, Pacini F, Schlumberger M, Sherman SI, Steward DL, Tuttle RM. Revised American Thyroid Association Management Guidelines for Patients with Thyroid Nodules and Differentiated Thyroid Cancer. Thyroid 2009;19:1167-1214.

11. Van Heerden JA, Hay ID, Goellner JR, Salomao D, Ebersold JR, Bergstralh EJ, Grant CS. Follicular thyroid carcinoma with capsular invasion alone: a nonthreatening malignancy. Surgery 1992;112:1130-1136.

12. Sanders LE, Cady B. Differentiated thyroid cancer: reexamination of risk groups and outcome of treatment. Arch Surg 1998;133:419-425.

13. Ito Y, Higashiyama T, Takamura Y, Kobayashi K, Miya A, Miyauchi A. Prognosis of patients with papillary thyroid carcinoma showing postoperative recurrence to the central neck. World J Surg 2011;35:767-772.

14. Davies L, Welch HG. Increasing incidence of thyroid cancer in the United States,1973-2002. JAMA 2006;295:2164-2167.

15. Luster M, Clarke SE, Dietlein M, Lassmann M, Lind P, Oyen WJ, Tennvall J, Bombardieri E; European Association of Nuclear Medicine (EANM). Guidelines for radioiodine therapy of differentiated thyroid cancer. Eur I Nucl Med Mol Imaging 2008;35:1941-1950.
16. Lombardi CP, Bellantone R, De Crea C, Paladino NC, Fadda G, Salvatori M, Raffaelli M. Papillary thyroid microcarcinoma: extrathyroidal extension, lymph node metastases, and risk factors for recurrence in a high prevalence of goiter area. World J Surg 2010;34:1214-1221

17. Mazzaferri EL, Kloos RT. Current approaches to primary therapy for papillary and follicular thyroid cancer. J Clin Endocrinol Metab 2001;86:1447-1463.

18. Machens $A$, Holzhusen $H J$, Dralle $H$. The prognostic value of primer tumor size in papillary and follicular thyroid carcinoma. A comparative analysis. Cancer 2005;103:2269-2273.

19. So YK, Son Y, Hong S.D, Seo MY, Baek C, Jeong H, Chung MK. Subclinical lymph node metastasis in papillary thyroid microcarcinoma: A study of 551 resections. Surgery 2010;148:526-531.

20. Ozkan E, Tokmak E, Tarı P, Küçük N.Ö, Yağcı Ş. Bone Metastases in Thyroid Carcinoma: A Retrospective Analysis. Turk J Nucl Med 2010;19:16-22.

21. Mazzaferri EL. The Diagnosis And Imaging of Thyroid Cancer. In: Amdur JA, Mazzaferri EL, editors. Essentials Of Thyroid Cancer Management. Springer Science+Business Media, Inc. 2005 p:39120.

22. Haugen BR, Lin EC. Isotope imaging for metastatic thyroid cancer. Endocrinol Metab Clin North Am 2001;30:469-492.

23. Verburg FA, Stokkel MP, Düren $C$, Verkooijen RB, Mäder $U$, van Isselt JW, Marlowe RJ, Smit JW, Reiners C, Luster M. No survival difference after successful 131-I ablation between patients with initially low-risk and high-risk differentiated thyroid cancer. Eur J Nucl Med Mol Imaging 2010;37:276-83.

24. Ito $Y$, Masuoka H, Fukushima M, Inoue H, Kihara M, Tomoda C, Higashiyama T, Takamura Y, Kobayashi K, Miya A, Miyauchi A. Excellent Prognosis of Patients with Solitary T1NOMO Papillary Thyroid Carcinoma Who Underwent Thyroidectomy and Elective Lymph Node Dissection Without Radioiodine Therapy. World J Surg 2010;34:1285-1290.

25. Fukushima M, Ito $Y$, Hirokawa M, Miya A, Shimizu K, Miyauchi A. Prognostic Impact of Extrathyroid Extension and Clinical Lymph Node Metastasis in Papillary Thyroid Carcinoma Depend on Carcinoma Size. World J Surg 2010;34:3007-3014. 